\title{
Unwanted obstetric and neonatal consequences of adolescent pregnancies
}

\section{Adölesan gebeliklerin istenmeyen obstetrik ve yenidoğan sonuçları}

\author{
Muzaffer TEMUR $^{1}$, Şükrü BUDAK ${ }^{2}$, Yasemin KILIÇ ÖZTÜRK ${ }^{3}$, Cihan KAYA ${ }^{4}$, Pelin Özün ÖZBAY ${ }^{5}$, \\ Özgür YILMAZ ${ }^{6}$
}

${ }^{I}$ Sağllk Bilimleri Üniversitesi Bursa Yüksek İhtisas Ĕ̆itim ve Araştırma Hastanesi Kadın Hastalıklarl ve Doğum Kliniği, Bursa ${ }^{2}$ Diyarbakır Kadın Hastalıkları ve Çocuk Hastanesi, Kadın Hastalıkları ve Doğum Kliniği, Diyarbakır

${ }^{3}$ Tepecik Ĕ̆itim ve Araştırma Hastanesi, Aile Hekimliği Kliniği, İzmir

${ }^{4}$ Bakırköy Dr. Sadi Konuk Ĕ̆itim ve Araștırma Hastanesi Kadın Hastalıkları ve Doğum Kliniğ i, İstanbul

${ }^{5}$ Aydin Özel Ege Liva Hospital, Aydin

${ }^{6}$ Manisa Merkez Efendi Devlet Hastanesi, Manisa

\section{ABSTRACT}

Objective: Adolescent pregnancies are one of the most important healthcare problems worldwide effecting social life and women health. We aimed to compare obstetric and neonatal outcomes between pregnancies of adolescent and women of reproductive age.

Methods: This study was conducted with adolescent and reproductive aged 3163 pregnant women who gave birth in our maternity and children's disease hospital between January 2013 and January 2014. Among them 1314 of them were adolescent pregnants aged under 20 years. The data for maternal age, gestational week at birth, mode of delivery, presence of operative delivery, birth weight, APGAR score, and number of premature births were recorded for each delivery.

Results: The rate of adolescent pregnancy was found as $6.35 \%$ in our study. The rate of premature births were $37 \%$ in adolescent group and significantly higher than reproductive age group $(\mathrm{p}<0.001)$. However preterm delivery was detected in 346 reproductive aged women with a rate of $19 \%$. 1st and 5th minute APGAR scores were significantly lower in the adolescent group (p values; $<0.001$, and $<0.001$, respectively). The mean birth weight was $3000 \pm 50 \mathrm{gr}$ in the adolescent, and age $3200 \pm 50 \mathrm{gr}$ in the reproductive age group..These parameters were statistically significantly lower in the adolescent group with p values $<0.001)$ Cesarean section rate was $17 \%$ in the dolescent group which was found to be statistically significant $(p<0,001)$.

Conclusion: Adolescent pregnacies are associated with poor obstetric and neonatal outcomes such as preterm labor, lower birth weight and lower APGAR scores.

Key words: Apgar score, newborn, adolescence

\section{$\ddot{\mathbf{O Z Z}}$}

Amaç: Adölesan gebelikler sosyal yaşamı ve kadın sağlığını etkileyen dünya çapındaki önemli sağlık sorunlarından biridir. Biz ergen ve üreme çağındaki kadınların gebelikleri arasındaki obstetrik ve neonatal sonuçları karşılaştırmayı amaçladık.

Yöntem: Bu çalışma, Ocak 2013 ve Ocak 2014 tarihleri arasında kadın doğum ve çocuk hastalıkları hastanemizde doğum yapan adölesan ve üreme çağındaki 3163 gebe ile yapılmıştır. Katılanların 1314'ünü 20 yaşından küçük adölesan gebeler oluşturmaktaydı. Doğum şekli, operatif doğum varlığı, doğum ağırlığı, APGAR skoru ve prematüre doğumların sayısı, anne yaşı, gebelik haftası gibi veriler her gebelik için kaydedildi.

Bulgular: Adölesan gebelik oranı çalışmamızda \%6,35 olarak bulundu. Prematüre doğumların oranı adölesan grubunda \%37 idi ve üreme çağındaki gruptan $(\mathrm{p}<0,001)$ anlamlı derecede yüksek bulundu. Ancak preterm doğum \%19'luk oran ile üreme çağındaki 346 kadında saptanmıştır. Birinci ve 5. dk. APGAR skorları adölesan grupta anlamlı olarak düşüktü (p değerlerinin sırasıyla, <0001, <0001). Ortalama doğum ağırlığı adölesan grup için $3000 \pm 50 \mathrm{~g}$ idi, ortalama doğum ağgrlığı üreme çă̆ındaki grup için ise $3200 \pm 50 \mathrm{~g}$ idi, bu parametreler adölesan grupta anlamlı olarak düşïktii $(p<0,001)$. Sezaryen oranı adölesan grupta \% 17 idi ve üreme çağındaki gruptan daha az görülmüş olup, bu farklılık istatistiksel olarak anlamlı bulunmuştur $(p<0,001)$.

Sonuç: Adölesan gebelikler preterm eylem, düşük doğum ağırlığı ve düşük APGAR skorları gibi kötü obstetrik ve yenidoğan sonuçları ile ilişkilidir.

Anahtar kelimeler: Apgar skoru, yenidoğan, adölesan
Alındığı tarih: 17.01.2016

Kabul tarihi: 29.01.2016

Yazışma adresi: Uzm. Dr. Muzaffer Temur, Sağlık Bilimleri Üniversitesi Bursa Eğitim ve Araştırma Hastanesi, Kadın Hastalıkları ve Doğum Kliniği, Bursa

e-mail: temurmuzaffer@gmail.com 


\section{INTRODUCTION}

Adolescent pregnancy is defined as any pregnancy occurring among teenage girls aged 19 years or younger. World Health Organization (WHO) statistics have reported a incidence of $11 \%$ for teenage pregnancies worldwide ${ }^{(1)}$. The adolescent pregnancy rate is varying between $8.7-11.8 \%$ in our country ${ }^{(2)}$.

Adolescent pregnancies are one of the most important problems worldwide in terms of economy, social life and health ${ }^{(3)}$. In developing countries, like ours, early marriage and early pregnancies are common due to cultural and socioeconomic conditions and lack of education ${ }^{(4)}$.

Many studies showed the association of early pregnancies with poor perinatal results. Low birth weight, premature birth and sudden loss of fetus are common in adolescent pregnancies ${ }^{(5)}$. The reason for these poor perinatal results were thought to be associated with physical immaturity and malnutrition of the mother, however this hypothesis remains controversial $^{(5)}$.

In this study we aimed to determine the obstetric and neonatal outcomes for adolescent pregnancies.

Materials and methods

This is a retrospective study including 1314 primipara adolescent pregnants with age of $\leq 19$ years who were delivered in Diyarbakır Maternity Hospital between the time period January 2013 and January 2014. 1850 healthy pregnant women who were delivered in the same time period with 20-45 years old age and single pregnancies were taken as control group. The rate of prematurity, birth weight, mode of delivery and APGAR (Activity, Pulse, Grimace, Appearance, Respiration) scores were evaluated. Multiple pregnanices, births under 22 weeks of gestation and fetuses with under 500 gr of weight, smoking pregnants, and pregnants with history of uterine surgery were excluded from the study. Preterm delivery was accepted before 37 th weeks of gestation. The gestational age was calculated by asking last menstrual period day. When gestational age by the last menstrual period and ultrasonographic biometry were inconsistent, the gestational age at birth was calculated according to the first thrimester CRL (crown rump lenght) measurement.

We included all eligible pregnants within the study without an a priori sample size calculation.

\section{Statistical analysis}

The mean and the median, standard deviation, ratios and frequencies were used in descriptive statistics. The distribution of the data were measured with Kolmogorov- Simirnov test. Mann Whitney U test were used in quantitative data and student $t$ tests were used in qualitative data. SPSS 22.0 Package Programme was used in analysis.

\section{RESULTS}

There was 20.050 deliveries during the study period in our hospital. The mean age was $18 \pm 1,1$ in adolescent age group and $28.7 \pm 5,8$ in reproductive age group (Table 1).

The mean week of gestation at birth was $37,6 \pm 2,5$ weeks, in adolescent age group, the mean week of gestation at birth was $38,6 \pm 2,3$ weeks, in reproductive age group this parameters were significantly lower in adolescent group with $\mathrm{p}$ values $<0,001$. The mean birth weight was in adolescent age group $3000 \pm 50 \mathrm{gr}$, and the mean birth weight was in reproductive age group $3200 \pm 50$ gr, this parameters were significantly lower in adolescent group with $\mathrm{p}$ values $<0,001$, APGAR score of 1 st minute was $7,6 \pm 1,1$ and 5th minute was 9,5 $\pm 1,3$ and all of these parameters were significantly lower in adolescent group with $\mathrm{p}$ values $<0,001,<0,001,<0,001,<0,001$, respectively. The preterm labor rate was significantly higher in adolescent group with 489 pregnancies with a rate of $37 \%$. However preterm delivery was with 346 reproductive aged women with rate of $19 \%$. This was also statistically different in adolescent group than the other group with $\mathrm{p}$ value $<0,001$. Ceaserian section was less common with a rate of $17 \%$ in adolescent group than the control group and this difference was statistically significant $(\mathrm{p}<0,001)$ (Table 1). 
Table 1. Comparison of adolescent group and reproductive aged group.

\begin{tabular}{|c|c|c|c|c|c|}
\hline & \multicolumn{2}{|c|}{ Adolescent group } & \multicolumn{2}{|c|}{ Reproductive aged group } & \multirow[b]{2}{*}{ p value } \\
\hline & Mean \pm SD $/ n-\%$ & Med(Min-Max) & Mean \pm SD $/ n-\%$ & Med(Min-Max) & \\
\hline Age & $18,0 \pm 1,1$ & $18(14-19)$ & $28,7 \pm 5,8$ & $28(20-45)$ & \\
\hline Gestational week & $37,6 \pm 2,5$ & $38(27-42)$ & $38,6 \pm 2,3$ & $39(26-42)$ & $<0,0001$ \\
\hline Birth weight (gr) & $3,000 \pm 50$ & $3,100(80-44)$ & $3,200 \pm 50$ & $3,200(70-51)$ & $<0,0001$ \\
\hline APGAR 1 st min & $7,6 \pm 1,1$ & $8(0-10)$ & $8,0 \pm 0,9$ & $8(0-10)$ & $<0,0001$ \\
\hline APGAR 5th min & $9,5 \pm 1,3$ & $10(0-10)$ & $9,8 \pm 0,8$ & $10(0-10)$ & $<0,0001$ \\
\hline Gestational week $<37$ & $489(37 \%)$ & & $346(19 \%)$ & & $<0,0001$ \\
\hline Gestational week $\geq 37$ & $825(63 \%)$ & & $1503(81 \%)$ & & \\
\hline Mode of delivery & & & $1266(68 \%)$ & & $<0,0001$ \\
\hline Vaginal & $950(72 \%)$ & & & & \\
\hline Cesarean section & $228(17 \%)$ & & $520(28 \%)$ & & \\
\hline Operative delivery & $136(10 \%)$ & & $63(3 \%)$ & & \\
\hline
\end{tabular}

\section{DISCUSSION}

Adolescent pregnacies are being considered as high risk group of pregnancies when compared with reproductive aged ones expediting perinatal and neonatal complications such as preterm labor, low birth weight and lower APGAR scores ${ }^{(2)}$. This could be due to inadequate maternal nutrition ${ }^{(7)}$, the lack of adequate maturation of the hypothalamohypophyseal axis for the maintenance of the pregnancy ${ }^{(8)}$, inadequate uterine and cervical maturation ${ }^{(9)}$ and the high rate of genitourinary tract infection in the early period adolescent group ${ }^{(10)}$.

There is contraversial reports on mode of delivery rates for adolescent and reproductive aged pregnancies in the literature. Tsikouras et al. have found a higher C-section rate in early period of adolescent pregnancies than normal age group pregnancies ${ }^{(11)}$. They speculated higher cesarean rates may be explained by cephalopelvic disproportion resulting with prolonged labor because of insufficient maturation of the maternal pelvis. We also found a high risk of operative labor in adolescents with a rate of $10 \%$.

However, in the study of Zeteroğlu et al ${ }^{(12)}$ among 40391 pregnant women, lower rates of cesarean section was found in adolescent pregnancies same as our results. This data is also the same with other reported studies in the literature ${ }^{(13,14)}$. We may speculate that this result could be explained with presence of more appropriate elastic connective tissue with adolescent pelvic organs 15 . It also can be explained with higher incidence of low birth weight fetuses with adolescent pregnancies thus delivery progress may not be affected by pelvic immaturity.

Many different studies have reported the relation of preterm labor and adolescent pregnancy in the literature ${ }^{(16,17)}$. In a study by Satin et al. a significant higher rate of preterm labor was obtained in pregnant women aged between 11-16 years among 16500 nulliparous women ${ }^{(18)}$. In studies from our country, the rate of preterm labor in adolescent pregnancies was reported as $7 \%-9.3 \%$ which is significantly higher than reproductive aged ones. Our study also supported these results by showing the significant difference of preterm labor in adolescent pregnancies with a rate of $5,7 \%$. We may explain this results with biologic immaturity of musculosceletal system and internal genital organs and elevated levels of prostoglandines that triggering preterm labor ${ }^{(19,20)}$.

We also found that babies of adolescent pregnancies had lower birth weights when compared to reproductive aged group. A study from USA showed that adolescent pregnancy is an independent risk factor for IUGR but in the study of Gordon et al., no significant difference of IUGR was observed between adolescent and adult pregnacies ${ }^{(21,22)}$.

Ezegwui et al (23) showed that the 1 st minute APGAR scores were significantly lower in adolescent pregnancies concordant with our results. This could be explained by increased risk of premature 
delivery in adolescent pregnants.

In conclusion adolescent pregnancies were considered as high risk group depending on the poor obstetric results. Many public educational programmes should be arranged by experts for prevention of adolescent pregnancies.

\section{Acknowledgements}

None

\section{Funding Statement}

This study did not receive any specific grant from any funding agency in the public, commercial or notfor-profit sector.

\section{Conflicts of interest}

The authors declare that there are no conflicts of interest.

\section{REFERENCES}

1. Mohd Azri MS, Adibah HI, Haliza G. A review of teenage pregnancy research in Malaysia. Med J Malaysia 2015;70:214-9.

2. Kaplanoglu M, Bülbül M, Konca C, Kaplanoglu D, Tabak MS, Ata B. Gynecologic age is an important risk factor for obstetric and perinatal outcomes in adolescent pregnancies. Women Birth 2015;28:e119-23.

http://dx.doi.org/10.1016/j.wombi.2015.07.002

3. Hanna B. Negotiating motherhood: the struggles of teenage mothers. J Adv Nurs 2001;34:456-64. http://dx.doi.org/10.1046/j.1365-2648.2001.01774.x

4. Sagili H, Pramya N, Prabhu K, Mascarenhas M, Reddi Rani P. Are teenage pregnancies at high risk? A comparison study in a developing country. Arch Gynecol Obstet 2012;285:573-7. http://dx.doi.org/10.1007/s00404-011-1987-6

5. Fraser AM1, Brockert JE, Ward RH. Association of Young Maternal Age with Adverse Reproductive Outcomes. N Engl J Med 1995;332:1113-7. http://dx.doi.org/10.1056/NEJM199504273321701

6. Chen X, Wen S, Fleming N, Demissie K, Rhoads G, Walker $\mathrm{M}$. Teenage pregnancy and adverse birth outcomes: a large population based retrospective cohort study. Int J Epidemiol 2007;36:368-73. http://dx.doi.org/10.1093/ije/dy1284

7. Scholl TO, Hediger ML, Ances IG, Cronk CE. Growth during early teenage pregnancies. Lancet 1988;1:701-2. http://dx.doi.org/10.1016/S0140-6736(88)91494-8

8. Zlatnik FJ, Burmeister LF. Low 'gynecologic age': an obstetric risk factor. Am J Obstet Gynecol 1977;128 (2):183-6. http://dx.doi.org/10.1016/0002-9378(77)90684-6
9. Da Costa AG, Mauad F, Ferreira AC, Spara P, Mauad FM. Uterine volume in adolescents. Ultrasound Med Biol 2004;30:7-10. http://dx.doi.org/10.1016/j.ultrasmedbio.2003.09.009

10. Heffner LJ, Sherman CB, Speizer FE, Weiss ST. Clinical and environmental predictors of preterm labor. Obstet Gynecol 1993;81(5 (Pt 1)):750-7.

11. Tsikouras P, Dafopoulos A, Trypsianis G, Vrachnis N, Bouchlariotou S, Liatsikos SA, et al. Pregnancies and their obstetric outcome in two selected age groups of teenage women in Greece. J Matern Fetal Neonatal Med 2012;25:1606-11. http://dx.doi.org/10.3109/14767058.2011.648242

12. Zeteroglu S, Sahin I, Gol K. Cesarean delivery rates in adolescent pregnancy. Eur J Contracept Reprod Health Care 2005; 10:119-22. http://dx.doi.org/10.1080/13625180500131600

13. Beyer DA, Amari F, Diedrich K, Bohlmann MK, Weichert J, Hornemann A. Teenage deliveries in Northern Germany: always a risk factor for higher surgical delivery rates? Arch Gynecol Obstet 2011;284:535-8. http://dx.doi.org/10.1007/s00404-010-1679-7

14. Sagili H, Pramya N, Prabhu K, Mascarenhas M, Reddi Rani P. Are teenage pregnancies at high risk? A comparison study in a developing country. Arch Gynecol Obstet 2012;285:573-7. http://dx.doi.org/10.1007/s00404-011-1987-6

15. Lao TT, Ho LF. Obstetric outcome of teenage pregnancies. Hum Reprod 1998;13:3228-32. http://dx.doi.org/10.1093/humrep/13.11.3228

16. Jolly MC, Sebire N, Haris J, Robinson S, Regan L. Obstetric Risks of Pregnancy in Women Less Than 18 Years Old. Obstet Gynecol 2000;96:9626. http://dx.doi.org/10.1097/00006250-200012000-00018

17. İngeç $M$, Börekçi $B$, Yılmaz $M$, Kadanalı S. Impact of Maternal Age on Perinatal Outcomes in Adolescent Pregnancies. J Turkish German Gynecol Assoc 2005;6:290-5.

18. Satin AJ, Leveno KJ, Sherman ML, Reedy NJ, Lowe TW, McIntire DD. Maternal youth and pregnancy outcomes: middle school versus high school age groups compared with women beyond the teen years. Am J Obstet Gynecol 1994;171:184-7. http://dx.doi.org/10.1016/0002-9378(94)90467-7

19. Cortes Castell E, Rizo-Baeza MM, Aguilar Cordero MJ, Rizo-Baeza J, Gil Guillén V. Maternal age as risk factor of prematurity in Spain; Mediterranean area. Nutr Hosp 2013;28:1536-40.

20. Bulut S, Gürkan A, Sevil Ü. Adolescent pregnancies. Aile ve Toplum Dergisi 2008;4:37-44.

21. Teng CL. Bibliography of clinical research in Malaysia: methods and brief results. Med J Malaysia 2014;69(Suppl A):4-7.

22. Smith GC, Pell JP. Teenage pregnancy and risk of adverse perinatal outcomes associated with first and second births: population based retrospective cohort study. BMJ 2001;323:1-5. http://dx.doi.org/10.1136/bmj.323.7311.476

23. Ezegwui HU, Ikeako LC, Ogbuefi F. Obstetric outcome of teenage pregnancies at a tertiary hospital in Enugu, Nigeria. Niger J Clin Pract 2012;15:147-50. http://dx.doi.org/10.4103/1119-3077.97289 